\title{
ANALISIS KUALITAS BUTIR SOAL UJIAN AKHIR SEMESTER GASAL MATA PELAJARAN PKSM KELAS XI TEKNIK SEPEDA MOTOR
}

\author{
Wulan Chikita \\ SMK Negeri 1 Bumiratu Nuban, Lampung \\ Email: wulanchikita@gmail.com
}

\begin{abstract}
This research was conducted with the aim to determine the quality of items about odd Semester Final Exam Subjects of Electrical Maintenance of Class XI Motorcycle Engineering at SMK Negeri 1 Bumiratu Nuban Academic Year 2018/2019. The research method used is descriptive method with a quantitative approach. The data collection technique uses the documentation method, to obtain test questions and answer keys as well as answers to all students who take the exam. The population of the study was grade XI Motorcycle Engineering SMK Negeri 1 Bumiratu Nuban 2018/2019. The results in terms of the question validity aspects as much as $57 \%$ including valid categories and $43 \%$ invalid. In terms of reliability, the reliability coefficient is 0.79 which means it has a high coefficient. Then in terms of the level of difficulty as much as 5\% including the easy category, 53\% including the medium category, 37\% including the difficult category and 5\% including the very difficult category. In terms of distinguishing factors, there were $5 \%$ of questions including excellent categories, $43 \%$ including good categories, $20 \%$ including sufficient categories, $22 \%$ including bad categories and 10\% including categories that had to be discarded. From the aspect of deceptive effectiveness, there are only $7.5 \%$ of questions for which all the deceivers function effectively.
\end{abstract}

Keywords: Item Analysis, ANATES Programme

\begin{abstract}
Abstrak
Penelitian ini dilakukan dengan tujuan untuk mengetahui kualitas butir soal Ujian Akhir Semester Gasal Mata Pelajaran Pemeliharaan Kelistrikan Sepeda Motor Kelas XI Teknik Sepeda Motor di SMK Negeri 1 Bumiratu Nuban Tahun Ajaran 2018/2019. Metode penelitian yang digunakan yaitu metode deskriptif dengan pendekatan kuantitatif. Teknik pengumpulan data menggunakan metode dokumentasi, untuk mendapatkan data soal ujian dan kunci jawaban serta jawaban seluruh peserta didik yang mengikuti ujian. Populasi penelitian ini yaitu siswa kelas XI Teknik Sepeda Motor SMK Negeri 1 Bumiratu Nuban tahun ajaran 2018/2019. Hasil penelitian ditinjau dari aspek validitas soal sebanyak 57\% termasuk katagori valid dan $43 \%$ tidak valid. Dari segi reliabilitas soal diperoleh koefisien reliabilitas sebesar 0,79 yang berarti memiliki koefisien tinggi. Kemudian dari segi tingkat kesukaran sebanyak 5\% temasuk katagori mudah, 53\% termasuk katagori sedang, 37\% termasuk katagori sukar dan 5\% termasuk katagori sangat sukar. Dilihat dari segi daya pembeda terdapat 5\% soal termasuk katagori baik sekali, $43 \%$ termasuk katagori baik, $20 \%$ termasuk katagori cukup, 22\% termasuk katagori jelek dan 10\% termasuk katagori yang harus dibuang. Dari aspek efektivitas pengecoh, hanya terdapat $7,5 \%$ soal yang seluruh pengecohnya berfungsi dengan efektif.
\end{abstract}

Kata kunci: Analisis Butir Soal, Program ANATES 


\section{PENDAHULUAN}

Perkembangan ilmu pengetahuan dan teknologi telah memberikan dampak positif maupun negatif dalam aspek kehidupan manusia, permasalahan yang timbul dapat dipecahkan dengan upaya peningkatan dan penguasaan ilmu pengetahuan dan teknologi. Adanya perkembangan ilmu pengetahuan dan teknologi juga membuat tidak adanya batasan antar manusia untuk berkomunikasi. Oleh karena itu, berkembangnya ilmu pengetahuan dan teknologi membawa manusia dalam persaingan global. Salah satu cara yang dapat ditempuh oleh suatu negara agar dapat bertahan dalam persaingan global yaitu dengan meningkatkan sumber daya manusia.

Pendidikan merupakan salah satu upaya untuk meningkatkan kualitas sumber daya manusia. Pendidikan adalah suatu hak bagi seluruh masyarakat yang harus dipenuhi dalam kehidupan bermasyarakat, berbangsa, dan bertanah air. Pendidikan yang baik adalah yang memiliki proses yang terarah dan jelas. Melalui pendidikan diharapkan dapat menciptakan sumber daya manusia (SDM) yang memiliki daya saing dan bermutu tinggi. Pengertian tentang pendidikan ini juga sesuai dengan undang-undang Nomor 20 tahun 2003 tentang pendidikan nasional yang menyatakan bahwa pendidikan adalah usaha dalam mewujudkan suasana belajar dan proses pembelajaran agar peserta didik secara aktif dapat mengembangkan potensi dirinya agar memiliki kekuatan spiritual keagamaan, pengendalian diri, kepribadian, kecerdasan, akhlak mulia, serta keterampilan yang diperlukan dirinya dan oleh masyarakat.

Perencanaan dan proses dalam pendidikan merupakan hal penting, namun tidak selayaknya sekarang ini kita hanya memperhatikan perencanaan dan prosesnya saja, tapi perlu dilakukan evaluasi dalam proses pelaksanaan pedidikan tersebut. Dalam konteks pendidikan, evaluasi dalam kelas dilakukan oleh setiap pendidik. Pendidik dapat mengetahui seberapa besar ketercapaian dari proses pembelajaran melalui evaluasi. Sekolah menengah kejuruan terus berupaya melakukan perkembangan untuk mencapai tujuan pembelajaran dengan membenahi perencanaan, sistem dan proses pembelajaran yang dilakukan dengan tidak mengutamakan bagaimana proses evaluasi dilakukan. Proses belajar mengajar yang dilakukan oleh guru harus selalu diperbaiki agar hasil yang ingin dicapai menjadi lebih baik. Penelitian yang dilakukan oleh Yuswono, Martubi, Sukaswanto, dan Budiman (2015) menyatakan bahwa kompetensi yang dimiliki oleh guru kejuruan masih kurang. Salah satu upaya dalam meningkatkan kualitas pendidikan dapat dilakukan peningkatan kompetensi guru dalam melakikan proses penilaian. Pada penilaian proses dan hasil belajar siswa di sekolah, aspekaspek yang berkenaan dengan pemilihan alat penilaian, penyusunan soal, pengolahan, dan 
interprestasi data hasil penilaian, analisis butir soal untuk memperoleh kualitas soal yang memadai, serta pemanfaatan data hasil penilaian sangat berpengaruh terhadap kualitas lulusan.

Penilaian menurut peraturan menteri pendidikan dan kebudayaan indonesia Nomor 23 Tahun 2016 mengenai standar penilaian menyatakan bahwa penilaian adalah proses pengumpulan dan pengolahan informasi untuk mengukur pencapaian hasil belajar peserta didik. Didalam pasal 5 juga disebutkan bahwa ada 9 prinsip penilaian hasil belajar yang dijadikan sebagai acuan yaitu sebagai berikut diantaranya adalah sahih, objekstif, adil, terpadu, terbuka, menyeluruh dan berkesinambungan, sistematis, beracuan kriteria dan akuntabel. Berdasarkan 9 prinsip penilaian seharusnya penilaian dilaksanakan sesuai dengan kemampuan peserta didik yang diukur serta tidak dipengaruhi subjektivitas penilaian.

Penilaian hasil belajar mengajar dapat diketahui dengan menggunakan alat yaitu instrument, dimana pendidik membuat instrumen ini dalam bentuk soal atau tes dengan kriteria soal yang telah ditentukan sehingga dapat menilai hasil belajar mengajar sesungguhnya. Munurut Suharsimi (2012: 57) sebuah tes dapat dikatakan baik sebagai alat ukur harus memenuhi persyaratan tes yaitu validitas, reabilitas, objektivitas, praktikabilitas dan ekonomis. Tes dikatakan valid apabila tes tersebut dapat dengan tepat mengukur apa yang hendak diukur. Tes yang reliable apabila tes tersebut memberikan hasil yang sama apabila diberikan berkali-kali ada subjek yang sama menunjukan ketetapan. Tes bersifat objektivitas bila tidak ada unsur subjektivitas yang mempengaruhi tes tersebut. Praktibilitas bila tes tersebut bersifat praktis yaitu mudah dilaksanakan.

Hasil Observasi menunjukan bahwa di SMK Negeri 1 Bumiratu Nuban masih belum memiliki kriteria yang jelas dari sisi evaluasi. Hal ini dikarenakan pendidik kurang memperhatikan kriteria pembuatan soal yang baik, ini biasanya disebabkan keterbatasan waktu yang digunakan untuk menyusun soal atau juga karena pendidik yang mengulur waktu dalam pembuatannya. sampai saat ini pembuatan soal belum berorientasi pada kemampuan siswa tetapi masih berdasarkan materi yang sudah diajarkan, bahkan soal tahun sebelumnya tidak jarang digunakan lagi ditahun selanjutnya.

Custer dalam Sudji Munadi (2009: 154) memberikan kritikan mengenai kelemahan dari program evaluasi di lembaga pendidikan kejuruan adalah kurang diperhatikannya evaluasi sebagai bahan program perencanaan, kebijakan dan review. Oleh karena itu, tes sebagai tolak ukur kemajuan peserta didik sudah selayaknya dibuat dengan sebaik-baiknya. Namun kendala yang dialami pendidik dari faktor internal sekolah adalah mereka cenderung kesulitan 
menyusun tes dikarenakan pengembangan sistem ujian belum terealisasi secara optimal disetiap sekolah. Seperti yang sudah kita ketahui bahwa sistem ujian umum jika pelaksanaannya di sekolah seperti hanya kegiatan musiman tanpa adanya kelangsungan sistem yang terintegrasi dalam pengembangan soal itu sendiri. Pengembangan teknik penyusunan soal harus didasarkan pada karakteristik bentuk soalnya. Pengukuran kompetensi bisa dilakukan dengan tes tertulis berbentuk soal objektif ataupun tes subjektif, ada kompetensi yang lebih tepat diukur menggunakan tes tertulis bentuk soal subjektif. Jadi, tidak semua perilaku harus ditanyakan dengan bentuk soal uraian atau objektif, mengingat setiap bentuk soal masing-masing mempunyai keunggulan dan kelemahan.

Keunggulan dan kelemahan setiap bentuk soal nantinya akan menjadi acuan pendidik untuk menyusun soal yang baik. Teknik penyusunannya juga didasarkan pada karakteristik dan bobot soal itu sendiri. Pendidik harus selektif dalam menyusun butir-butir soal sebelum di uji cobakan terhadap peserta didik. Hal ini bisa diketahui melalui hasil evaluasi yang sudah dilaksanakan selama satu semester dimana terjadi ketimpangan diantara nilai 3 mata pelajaran yang sedang diajarkan pada semester gasal tahun ajaran 2018/2019 di SMK Negeri 1 Bumiratu Nuban.

Mata pelajaran Pemeliharaan Mesin Sepeda Motor (PMSM) dan Pemeliharaan Chasis Sepeda Motor (PCSM) sudah menunjukan bahwa nilai siswa dapat mencapai standar ketuntasan belajar minimal yang ditetapkan. Namun berbeda dengan mata pelajaran Pemeliharaan Kelistrikan Sepeda Motor (PKSM), dimana hanya ada beberapa siswa yang dapat mencapai standar ketuntasan belajar minimal.

Hasil diskusi dengan guru mata pelajaran Pemeliharaan Kelistrikan Sepeda Motor kelas XI di SMK Negeri 1 Bumiratu Nuban menghasilkan beberapa faktor yang mempengaruhi rendahnya nilai rata-rata ujian akhir semester gasal mata pelajaran pemeliharaan kelistrikan sepeda motor, salah satunya yaitu selama ini pihak sekolah belum melaksanakan pengawasan secara ketat terkait soal yang akan diujikan ke peserta didik dan soal yang digunakan untuk ujian digunakan secara berulang-ulang. Guru menganggap soal yang digunakan masih relevan dan layak digunakan. Selain itu, guru juga tidak melakukan proses analisis yang mendalam karena menganggap soal yang digunakan tidak jauh beda dengan soal sebelumnya sehingga kualistas butir soal tersebut belum diketahui untuk menghasilkan soal yang berkualitas. Untuk tataran yang lebih mendalam yaitu menganalisis butir soal agar dapat diketahui kualitasnya. Melalui analisis butir soal ini dapat diperoleh informasi tentang ketidaklayakan sebuah soal dan petunjuk dalam mengadakan perbaikannya. 
Dalam analisis butir soal ada beberapa bagian diantaranya analisis validitas, reliabilitas, tingkat kesukaran, daya pembeda, dan efektivitas pengecoh. Menganalisis validitas dan reliabilitas yaitu mengkaji kelayakan soal dalam menentukan aspek mana yang harus diukur dan konsistensi soal. Tingkat kesukaran soal artinya mengkaji soal dari segi kesulitannya sehingga dapat diperoleh soal mana yang termasuk mudah, sedang dan sukar. Sedangkan menganalisis daya pembeda artinya mengkaji soal dari segi kesanggupan soal tersebut dalam membedakan siswa yang termasuk tinggi prestasinya dan fungsi pengecoh berarti seberapa efektif alternatif jawaban sebagai pengecoh. Analisis butir soal sebagai usaha untuk mengetahui kualitas soal harus dilakukan. Hal ini karena soal tersebut digunakan sebagai pertimbangan dalam menentukan kualitas pendidikan. Berdasarkan permasalahan yang diuraikan, peneliti memandang bahwa analisis butir soal perlu dilakukan untuk mengetahui kualitas perangkat tes, sehingga bisa digunakan sebagai bahan evaluasi pembuatan soal mendatang.

Berdasarkan latar belakang masalah yang telah dikemukakan dapat diidentifikasi beberapa masalah yang dapat diteliti: 1) Terdapat perbedaan nilai yang signifikan pada mata pelajaran Pemeliharaan Kelistrikan Sepeda Motor, Pemeliharaan Mesin Sepeda Motor dan Pemeliharaan Chasis Sepeda Motor pada semester yang sama. 2) Satuan pendidikan tidak memberikan bimbingan yang maksimal mengenai prosedur pembuatan soal yang sesuai dengan kemampuan peserta didik. 3) Soal yang digunakan untuk ujian akhir semester tidak jarang hanya diambilkan dari soal ujian akhir semester tahun sebelumnya. 4) Belum pernah dilakukan analisis butir soal pada soal ujian akhir semester gasal mata pelajaran Pemeliharaan Kelistrikan Sepeda Motor kelas XI di SMK Negeri 1 Bumiratu Nuban tahun ajaran 2018/2019.

Berdasarkan uraian diatas, maka rumusan masalah pada penelitian ini adalah: Bagaimanakah kualitas butir soal ujian akhir semester gasal mata pelajaran PKSM kelas XI TSM di SMK Negeri 1 Bumiratu Nuban tahun ajaran 2018/2019 berdasarkan analisis empiric yang meliputi tingkat kesukaran, daya pembeda, reliabilitas, validitas dan efektifitas pengecoh?

Dengan tujuan penelitian diatas, diharapkan akan memberikan manfaat: 1) Secara teoritis: Hasil penelitian ini dapat dijadikan sumber bahan informasi yang penting bagi para peneliti lain untuk melakukan penelitian sejenis atau melanjutkan penelitian ini secara lebih mendalam. 2) Secara Praktis: a) Bagi Peneliti: Dapat menambah wawasan dan pengalaman mengenai analisis butir soal serta dapat digunakan sebagai bekal apabila menjadi pendidik 
dimasa yang akan datang. b) Bagi Sekolah: Dapat digunakan untuk menentukan kebijakan terkait upaya meningkatkan pembelajaran melalui analisis kualitas butir soal yang akan diujikan kepada peserta didik sebagai bentuk upaya peningkatan hasil belajar.

\section{METODE PENELITIAN}

\section{Desain Penelitian}

Penelitian ini merupakan penelitian deskriptif kuantitatif, artinya data yang dianalisis tidak untuk menerima atau menolak hipotesis, melainkan hasil analisis itu berupa deskripsi gejala-gejala yang diamati, yang berbentuk angka-angka atau koefisien antar variabel. Analisis secara kuantitatif dilakukan dengan menggunakan program ANATES yang hasilnya meliputi tingkat kesukaran, daya pembeda, dan efektifitas distractor serta reliabilitas soal.

\section{Waktu dan Tempat Penelitian}

Penelitian ini dilaksanakan di SMK Negeri 1 Bumiratu Nuban beralamat di Jalan Pandawa, Wates, Kec. Bumiratu Nuban, Kab.Lampung Tengah, Lampung. Waktu penelitian ini dilaksanakan pada Februari 2019.

\section{Subjek dan Objek Penelitian}

Subjek dalam penelitian ini adalah seluruh siswa kelas XI jurusan Teknik Sepeda Motor SMK Negeri 1 Bumiratu Nuban Tahun Ajaran 2018/2019 yang terdiri dari 45 peserta didik kelas XI TSM A dan XI TSM B. Objek penelitian ini adalah Soal Ujian Akhir Semester Gasal Mata Pelajaran Pemeliharaan Kelistrikan Kelas XI Kompetensi Keahlian Teknik Sepeda Motor SMK Negeri 1 Bumiratu Nuban Tahun Ajaran 2018/2019 beserta kunci jawaban dan respon jawaban siswa dan kisi-kisi soal.

\section{Teknik Pengumpulan Data}

Teknik yang digunakan untuk mengumpulkan data adalah teknik dokumentasi. Dokumentasi bertujuan untuk mendapatkan data penelitian yang berupa daftar nama siswa, silabus, soal, lembar jawaban Ujian Akhir Semester Gasal Mata Pelajaran PKSM Kelas XI TSM SMK Negeri 1 Bumiratu Nuban. 


\section{Teknik Analisis Data}

Teknik analisis data menggunakan analisis kuantitatif dengan Program Anates yang meliputi validitas, reliabilitas, tingkat kesukaran, daya pembeda dan efektivitas pengecoh.

\section{HASIL PENELITIAN DAN PEMBAHASAN}

\section{Validitas}

Berdasarkan hasil analisis 40 butir soal yang telah dilakukan diketahui bahwa soal yang termasuk dalam katagori valid yaitu sebanyak 23 butir soal (57\%). Sedangkan soal yang termasuk katagori tidak valid berjumlah 17 butir soal (43\%). Apabila 40 soal tersebut didistribusikan berdasarkan indeks validitasnya maka didapatkan hasil sebagai berikut:

Tabel 1. Indeks Validitas Soal

\begin{tabular}{|c|c|c|c|}
\hline Indeks Validitas & Nomor Butir Soal & Jml & $\begin{array}{c}\text { Persen } \\
\text { tase }\end{array}$ \\
\hline Valid & $\begin{array}{l}1,2,3,4,6,7,8,14,17,18,19,20,21,22,23,24,25,26,28,29,31 \\
37,39\end{array}$ & 23 & $57 \%$ \\
\hline Tidak Valid & $5,9,10,11,12,13,15,16,27,30,32,33,34,35,36,38,40$ & 17 & $43 \%$ \\
\hline
\end{tabular}

Tabel diatas menjelaskan bahwa terdapat soal yang valid dan tidak valid. Anas Sudijono (2012:183) mengungkapkan bahwa butir soal yang memiliki validitas tinggi mencerminkan bahwa soal tersebut telah memiliki kehandalan dan tidak perlu diragukan ketepatannya dalam mengukur kemampuan peserta didik. Untuk butir soal yang memiliki validitas rendah mencerminkan soal tersebut tidak valid sehingga perlu dilakukan tindakan terhadap soal tersebut.

\section{Reliabilitas}

Berdasarkan hasil analisis soal pilihan ganda mata pelajaran pemeliharaan kelistrikan sepeda motor menggunakan program anates versi 4.0.9 dapat diketahui bahwa reliabilitas soal sebesar 0,79. Hasil ini dilihat dari besarnya korelasi alpha. Dengan hasil ini maka dapat dikatakan bahwa reliabilitas tes untuk soal pilihan ganda mata pelajaran kelistrikan ini dikatakan baik karena reliabilitasnya memiliki nilai diatas 0,7 .

\section{Tingkat Kesukaran}


Setelah dilakukan analisis butir soal pilihan ganda dapat diketahui bahwa pada soal tidak terdapat soal yang berkatagori sangat mudah, sebanyak 2 butir soal termasuk dalam katagori mudah, 21 butir soal termasuk dalam katagori sedang, 15 soal termasuk dalam katagori sukar dan 2 soal termasuk katagori sangat sukar. Distribusi soal berdasarkan tingkat kesukaran dapat dilihat pada table berikut.

Tabel 2. Perhitungan Tingkat Kesukaran

\begin{tabular}{cccc}
\hline Katagori & Jml. & Persentase & Nomor Soal \\
\hline Mudah & 2 & $5 \%$ & 1,5 \\
Sedang & 21 & $53 \%$ & $2,3,4,6,7,8,9,14,16,19,20,21,22,24,25,26,27,31,37$, \\
& & & 39,40 \\
Sukar & 15 & $37 \%$ & $10,11,12,15,17,18,23,28,29,32,33,34,35,36,38$ \\
Sangat Sukar & 2 & $5 \%$ & 13,30 \\
\hline
\end{tabular}

Dari tabel diatas dapat diketahui tingkat kesukaran butir soal hasil analisis belum sesuai dengan idealnya. Soal yang mudah hanya sejumlah 5\% sedangkan idealnya yaitu sebesar $30 \%$ sehingga soal didominasi dengan soal sedang sebesar 52\% dan soal sukar menjadi $43 \%$. Hal ini menjadikan siswa terlalu tegang dalam berpikir sehingga tidak rileks dalam mengerjakan soal ujian.

\section{Daya Pembeda}

Berdasarkan hasil analisis daya pembeda terhadap 40 butir soal pilihan ganda dapat diketahui bahwa sebanyak 2 butir soal termasuk dalam katagori soal yang baik sekali, 17 soal dalam katagori baik, 8 soal dalam katagori cukup, 9 soal dalam katagori jelek dan 4 soal masuk dalam katagori butir saol yang harus dibuang. Distribusi sebaran soal berdasarkan daya pembeda dapat dilihat pada tabel 3.

Tabel 3. Perhitungan Daya Pembeda

\begin{tabular}{cccc}
\hline Katagori & Jml. Soal & Persentase & Nomor Soal \\
\hline Dibuang & 4 & $10 \%$ & $32,35,36,38$ \\
Jelek & 9 & $22 \%$ & $5,9,10,13,16,27,30,33,40$ \\
Cukup & 8 & $20 \%$ & $1,2,11,15,18,25,34,39$ \\
Baik & 17 & $43 \%$ & $3,4,8,12,14,17,19,20,21,22,23,24,26,28,29,31,37$
\end{tabular}

Baik Sekali

Berdasarkan tabel dapat diketahui bahwa $67 \%$ butir soal termasuk dalam katagori memadai untuk diujikan sedangkan 33\% soal memiliki daya beda lemah. Soal pada kriteria 
diterima atau baik berarti soal tersebut mempunyai kemampuan untuk membedakan antara siswa yang sudah memahami materi dan siswa yang belum memahami materi. Soal pada kriteria tidak diterima/ tidak dapat dipakai maka harus dibuang karena tidak dapat membedakan antara siswa yang memahami materi dan siswa yang belum memahami materi. Suatu soal tidak dapat membedakan antara siswa yang memahami materi dan siswa yang belum memahami materi dimungkinkan karena kunci jawaban soal tidak tepat, butir soal mempunyai dua atau lebih jawaban soal, kompetensi yang diukur tidak jelas, pengecoh tidak berfungsi, dan materi yang ditanyakan terlalu sulit.

\section{Efektivitas Pengecoh}

Analisis butir soal dari segi efektifitas pegecoh ini dilakukan dengan tujuan untuk mengetahui seberapa baik pilihan yang salah dari jawaban soal yang dapat mengecoh peserta tes yang memang tidak mengetahui kunci jawaban yang tersedia. Untuk mengetahui efektifitas dari pengecoh tersebut dapat dilakukan dengan cara melihat pola sebaran jawaban soal dari para peserta didik. Berdasarkan dari pola sebaran inilah akan diketahui apakah fungsi pengecoh dapat berfungsi dengan baik atau tidak.

Berdasarkan hasil analisis efektivitas pengecoh dapat diketahui bahwa hanya ada 3 butir soal yaitu nomor 21, 35, dan 39 yang efektif digunakan sebabai pengecoh dan 37 butir soal lainnya memiliki beberapa pengecoh yang tidak efektif dugunakan. Pengecoh yang tidak efektif yaitu pengecoh yang tidak bisa membedakan kelompok unggul dan asor selain itu hal lain yang menyebabkan pengecoh tidak berfungsi yaitu lebih banyak soal yang tingkatannya sedang dan sukar. sedangkan pengecoh yang efektif memiliki kriteria yaitu mirip dengan kunci, dipilih minimal 5\% peserta tes yang banyak memilih dari kelompok asor.

\section{SIMPULAN}

Berdasarkan pembahasan hasil penelitian yang telah diuraikan sebelumnya, maka diperoleh kesimpulan sebagai berikut:

1. Hasil analisis butir soal dari segi validitas menunjunkan bahwa soal yang valid berjumlah 23 butir soal (57\%) dan tidak valid yaitu 17 butir soal (43\%).

2. Hasil analisis butir soal dari segi reliabilitas menunjukkan angka 0,79 sehingga berarti soal memiliki nilai reliabilitas yang tinggi. 
3. Hasil analisis butir soal dari segi tingkat kesukaran diketahui bahwa 2 butir soal (5\%) termasuk dalam katagori mudah, 21 butir soal (53\%) termasuk katagori sedang, 15 butir soal (37\%) termasuk katagori sukar dan 2 butir soal masuk dalam katagori sangat sukar.

4. Hasil analisis butir soal dari segi daya pembeda diketahui bahwa 2 butir soal (5\%) termasuk dalam katagori baik sekali, 17 butir soal (43\%) termasuk katagori baik, 8 butir soal (20\%) termasuk katagori cukup, 9 (22\%) butir soal termasuk katagori jelek dan 4 butir soal (10\%) masuk dalam katagori butir soal yang harus dibuang.

5. Hasil analisis butir soal dari segi efektivitas pengecoh hanya terdapat 3 butir soal $(7,5 \%)$ yang seluruh pengecohnya berfungsi dengan efektif.

\section{DAFTAR PUSTAKA}

Anas Sudijono. (2012). Pengantar Evaluasi Pendidikan. Jakarta: PT. Raja Grafindo Persada

Depdiknas. (2003). Undang-undang RI No. 20 Tahun 2003 Tentang Sistem Pendidikan Nasional.

Kemendikbud. (2016). Permendikbud No 23 Tentang Standar Penilaian Pendidikan. Jakarta: Kemendikbud

Sudji Munadi, S. (2009). Analisis Daya Prediksi Tes Seleksi Masuk Program D3 Reguler Fakultas Teknik Universitas Negeri Yogyakarta Terhadap Prestasi Akademik Mahasiswa D3 Teknik FT UNY. JPTK, 18, 154.

Suharsimi Arikunto. (2012). Dasar-Dasar Evaluasi Pendidikan. Jakarta: Bumi Aksara.

Yuswono, L. C., Martubi, Sukaswanto, \& Budiman, A. (2015). Profil Kompetensi Guru SMK Teknik Kendaraan Ringan di Daerah Istimewa Yogyakarta. Penelitianpendidikan, 438. 